\title{
Determination of Digital Citizenship Levels of University Students at Sakarya University Turkey
}

\author{
Ezgi Pelin Yıldız ${ }^{1}$, Metin Çengel ${ }^{1} \&$ Ayșe Alkan ${ }^{1}$ \\ ${ }^{1}$ Kafkas University Kazım Karabekir Vocational School of Technical Sciences Department of Computer \\ Programming, Sakarya University of Applied Sciences Hendek Vocational School Department of Computer \\ Programming, Samsun Provincial Directorate of National Education \\ Correspondence: Ezgi Pelin Yıldız, Kafkas University Kazım Karabekir Vocational School of Technical Sciences \\ Department of Computer Programming, Sakarya University of Applied Sciences Hendek Vocational School \\ Department of Computer Programming, Samsun Provincial Directorate of National Education
}

Received: March 28, 2020

Accepted: April 23, 2020

Online Published: April 24, 2020

doi:10.5430/ijhe.v9n3p300

URL: https://doi.org/10.5430/ijhe.v9n3p300

\begin{abstract}
When digital transactions such as official transactions, banking transactions, communication, education, production, shopping are carried out in digital environment, the concept of digital citizenship has emerged. Digital citizenship; it is the person who has the ability to use information technologies appropriately and correctly in areas such as official transactions, social communication, education, and production. As technology improves, problems with its use increases exponentially. So technological behavior or technological citizenship it is clear that the behavior, values, ethical rules and awareness should be created. In this study in order to detection this awareness; it is aimed to determine the digital citizenship levels of university students. For this purpose, 253 students studied in various departments of the Hendek Vocational High School of Technical Sciences in Sakarya university. The research was carried out with the relational scanning model from the quantitative research method. "Digital Citizenship Scale for Youth" was developed by Kus, Gunes, Basarmak and Yakar (2017) the researcher as a data collection tool with permission. The scale has 49 items, the total variance of the scale was determined that the scale had 8-factor structure and was found to be $49,70 \%$. Related dimensions are communication, jus and responsibility, critical thinking, participation, security, digital skills, ethics and commerce. In the analysis of the data, non-parametric tests were used in addition to the percentage, frequency and standard deviation values. As a result; students were revealed to be aware of digital citizenship's sub-dimension.
\end{abstract}

Keywords: digital citizenship and its dimensions, technological behavior, technological citizenship, university students

\section{Introduction}

The changes and transformations experienced with technology also brought new concepts to human life. Digital literacy, digital citizenship, digital gap, digital concepts such as locality and digital immigration are some of the concepts that have become important in social life (Akgün, Yılmaz and Seferoğlu, 2011). Digital transformation that affects the society deeply changes the individuals living in the information society and their digital identity. and caused individuals to be referred to as "digital citizenship" (Gülseren et al., 2013).

The concept of digital citizenship aims to prepare children, who are new individuals of the digital world in which they live, for a society using technology. According to Ribble and Bailey (2007), the concept of digital citizenship is gained from an early age. For this reason, citizenship education should evolve to suit the needs of young citizens and the social, political and communication worlds they live in (Bennet, Wells and Rank, 2009). When using digital citizenship technology, it is stated as considering the basic norms and acting in this direction. At the definitions of digital citizenship, it is seen that active participation in digital environments comes first (Karaduman and Oztürk, 2014).

NETS-S standards; indicates the knowledge and skills that students should have for efficient learning in an increasingly digital world. Among these standards is being a digital citizenship (ISTE, 2014). Digital citizenship granted within the ISTE (2014) standards legal and ethical behavior of students on issues related to human, culture, society and technology includes understanding. This standard allows students to use information technologies in a 
safe, legal way. It includes sub-dimensions such as showing positive behaviors related to the use of technology that supports use, collaboration, learning and productivity, being responsible for lifelong learning and showing leadership behavior for digital citizenship.

Ribble and Bailey (2007) define 9 dimensions related to the concept of digital citizenship. In these definitions, it is seen that emphasis is placed on competence (skills) and ethical rules in digital environments.

- Digital Access: Access to digital resources from any environment and at any time.

- Digital Commerce: Purchase and sale of goods and services in digital media.

- Digital Communication: Information exchange in digital environment.

- Digital Literacy: Knowledge and skills on when and how to use technology.

- Digital Ethics: Behavioral standards expected from digital technology users.

- Digital Law: Legal jus and restrictions on technology use.

- Digital Jus and Responsibilities: Freedoms of digital technology users.

- Digital Health: Physical and psychological elements that arise with the use of digital technology.

- Digital Security: Network and personal information security of digital tool users.

\subsection{Literature Review}

When the literature is examined, it is determined that there are many studies on digital citizenship. In this context Kus, Gunes, Basarmak and Yakar (2017) studied the determination of digital citizenship levels of young people they have developed a scale in this scope. It was determined that this scale is a valid and reliable tool that can be used to determine the perception of digital citizenship of young people.

Tawalbe (2017) identified the degree of embedding digital citizenship concepts in national and civic educational textbooks, and the familiarity of teachers with digital citizenship concepts. Results also revealed the absence of the teachers' knowledge of national and civic education of the ayes and concepts of digital citizenship.

Jwaifell (2018), studied of investigate the technology usage as a digital citizenship indicator among undergraduate 310 English language students at Al-Hussein Bin Talal University (AHU). Results of the study revealed that students do not properly use technologies as a digital citizenship indicator.

Vural and Kurt (2018) studied of investigation of dijital citizenship indicators by university students 'view. In this context, they studied with 625 students in various departments of a university. As a result; it has been determined that digital citizenship averages increase as the grade level increases, and the correlations between internet usage frequencies and monthly incomes and their general averages are significant.

Dedebali and Dasdemir (2019), studied the determination of social studies teacher candidates' perception of digital citizenship. The study is composed of 180 senior teacher candidates attending the Social Studies Teaching Department. The analysis of the results in the context of sub dimensions indicates that no statistically significant difference was found by the gender variable, however significant differences was observed in digital citizenship levels of the teacher candidates according to the variables of owning a personal computer, age and years of experience in computer use.

The purpose of this study in this context; the digital citizenship levels of university students. For this purpose, 253 students studied in various departments of the Hendek Vocational High School of Technical Sciences in Sakarya university. By answering the following sub-goal:

Q1: Do the digital citizenship levels of university students differ according to their demographic characteristics (age, classroom, department, place of residence, family economic situation, computer and internet usage habits) ?

Q2: Considering the dimensions of digital citizenship, which dimension is at the forefront for university students?

With the development of technology and the existence of the internet in every area of our lives, the responsibility of being "a good digital citizenship" came with it. Individuals' identity in the internet world and social media are described as "digital citizenship".

Digital citizenship continues to be among the most spoken terms of recent days. As technology evolves, problems with its use are increasing exponentially and exponentially. Therefore, it is clear that the behavior, values, ethical rules and consciousness related to technological behavior or technological citizenship should be created. In this study, university students were selected as samples; because young people are the guarantee of the future of the countries. 
At this point, this young generation, who lives with technology, knows how conscious they are when using digital tools and environments and a good digital it is important to reveal whether they continue their existence as citizens.

In this context; determining students' level of awareness about digital citizenship is considered important and this study was deemed necessary. It is clear that the results of the study will guide the researchers and suggestions will be included in this context.

\section{Method}

This research was carried out with the relational screening model, which is one of the quantitative research methods. Relational scanning model; it is often used to determine the presence and amount of interaction between multiple variables. These relationships are determined by statistical methods such as correlation, $t$ test, variance analysis, multiple regression analysis (Cresswell, 2007; Buyukozturk, 2018).

\subsection{Sample Group}

In this study, in order to determine the digital citizenship levels of university students, a total of 253 students studying at various departments at the Sakarya University Hendek Technical Sciences Vocational School were choosed as sample group.

\subsection{Sampling Method}

Random sampling in purposeful sampling is used in this study. Purposeful sampling allows for deep research by selecting information rich situations depending on the purpose of the study (Buyukozturk, 2018).

\subsection{Data Collection Tool}

"Digital Citizenship Scale for Youth" was developed by Kus, Gunes, Basarmak and Yakar (2017) the researcher as a data collection tool with permission. The scale has 49 items, the total variance of the scale was determined that the scale had 8-factor structure and was found to be $49,70 \%$. Five-grade options are presented to determine the degree of students' participation in the expressions expressed in the items against the created items. These options are scored as "(5) Strongly Agree", "(4) Agree", "(3) Undecided", "(2) Disagree", "(1) Strongly Disagree". For the validity of the scale, the KMO value was determined as 0.827. It is acceptable for Kaiser-Mayer- Olkin (KMO) value to exceed .60, and as this value increases, the value obtained as a result of the Barlett Test will increase (Foster, Barkus and Yavorsky, 2006). Therefore, it can be said that the data are suitable for factor analysis according to the KMO value obtained.

\subsection{Analysis of Data}

SPSS (Statistical Package for Social Sciences) version 24 was used to evaluate the data obtained from the research and to create tables. Percentage (\%), average $(\bar{x})$, frequency (f) and standard deviation (SD) values were used in the analysis of the data collected to answer the research questions. Within the scope of the Kolmogorov-Smirnov test, it was accepted that the data showed a normal distribution since $\mathrm{p}<.05$ was obtained. In this context, non parametric tests in the research. The mean and standard deviation values of the items for the relevant scale were determined with the help of tables.

In this study, non parametric tests: Mann Whitney and Kruskal Wallis $\mathrm{H}$ tests were used in the analysis of the data. If the dependent variable with two sub-groups and the dependent variable is of the ordered (may be continuous) data type, Mann-Whitney U Test is basically performed. Kruskal Wallis H test which is a technique used to test the significance of the difference between the averages of three or more groups in groups that do not have a normal distribution. Also, Spearman Brown correlation coefficient was used to test the linearity of the relationship between the two variables (Buyukozturk, 2018).

\section{Findings}

Demographic information of the sample group is given in the sentences below:

The participants of the research 174 of them were male and 17 were female. Their ages range from 18 to 66 ; but the density is between 18-21 years. Students' departments are mostly Information Technologies.

Students' living places are mostly province. When students' the education level of the mother is examined more primary school graduates. When students' the education level of the father is examined more primary school graduates too.

The vast majority of students stated that there is no internet in their home. Connection tool has been found to be more computers. In addition students' daily internet usage is mostly 3 hour and more. It was revealed that the 
students' purpose of internet use is mostly to use social media.

Analysis results (including mean (( $\overline{\mathbf{x}})$ mean) and standard deviation (SD) values) of the scale items are given in Table 2.

Table 1. Average and Standard Deviation Values of Digital Citizenship Scale for Youth scale Items

Items and Factor

\section{Dimension I: Digital Communication}

M1. I do not mind if anyone shares my posts on social media.

M2. I send pictures, videos or information to someone I don't know

M3. If comments containing bullying and rudeness were made to my posts, I would respond in the same way.

\begin{tabular}{llrr}
\hline M4. & I like to share everything I do on social media (facebook, twitter etc.) & 2.51 & 1.293 \\
\hline M5. & I communicate with people I do not know digital environment. & 1.99 & .861 \\
\hline M6. I use abbreviations in my digital media. & 2.54 & 1.170
\end{tabular}

\section{Dimension II: Digital Responsibility}

3.14

1.137

M7. I complain about the situations that disturb me in the digital environment to the relevant $1.93 \quad 1.219$ units

\begin{tabular}{lc}
\hline M8. I stay away from all kinds of insulting things in digital media. & 3.75 \\
\hline $\begin{array}{l}\text { M9. When I communicate on the Internet, I know that my freedom is finish where } \\
\text { someone else's freedom begins. }\end{array}$ & 3.64 \\
\hline M10. I actively use my e-government account. & 3.11 \\
\hline $\begin{array}{l}\text { M11. I use the e-complaint system (BIMER, CIMER etc.) on issues that I think I have been } \\
\text { unfair to. }\end{array}$ & 3.67 \\
\hline M12. I do not know exactly the rights I have in digital media & 3.17 \\
\hline $\begin{array}{l}\text { M13. Hiding my identity on the internet, I display behaviors that I have not adopted in real } \\
\text { life. }\end{array}$ & 3.02 \\
\hline M14. I do not use websites with inappropriate content (racism, bigotry and rudeness). & 1.229 \\
\hline M15. I log in in different ways to sites with blocked access. & 1.81 \\
\hline Dimension III: Critical Thinking & 4.19 \\
\hline $\begin{array}{l}\text { M16. Internet is a reliable source in economic, political and social issues. } \\
\text { M17. I will participate to campaigns in digital media after examining in detail. }\end{array}$ & 1.064 \\
\hline M18. I criticize the things I find unfair on the Internet. & $\mathbf{2 . 8 1}$ \\
\hline M19. I accept the accuracy of the information I read digitally without question. & $\mathbf{1 . 1 0 7}$ \\
\hline M20. My friends' posts are reliable to me. & 2.64 \\
\hline M21. The information I read digitally affects my thoughts and decisions in daily life. & 1.445 \\
\hline M22. I use the information without investigating the accuracy of a shared it. & 3.91 \\
\hline
\end{tabular}

\section{Dimension IV: Digital Participation}

\begin{tabular}{lcc} 
& $\mathbf{3 . 1 5}$ & $\mathbf{6 8 8 . 4}$ \\
\hline M23. I support a social, economic and cultural campaign launched through digital media. & 1.88 & .865 \\
\hline M24. I contact the official institutions via the Internet about the events I consider important. & 3.26 & .939 \\
\hline $\begin{array}{l}\text { M25. Collaborate with other people on digital media for problems that concern my city, } \\
\text { country or the world. }\end{array}$ & 3.38 \\
\hline M26. In digital media, I exercise my right to obtain information from official institutions. & 3.26 & 1.058 \\
\hline M27. I express my thoughts about the events that I consider important in social media. & 4.01 & .721 \\
\hline
\end{tabular}




\begin{tabular}{|c|c|c|}
\hline Dimension V: Digital Security & 2.56 & 1.027 \\
\hline M28. When I am online, I share my personal information with people I do not know. & 3.34 & 1.088 \\
\hline M29. I click on any connection that comes to me in digital media. & 1.45 & .674 \\
\hline M30. I use an anti-virus program for my security in digital media. & 1.56 & .736 \\
\hline M31. I download all kinds of programs I need from digital media. & 3.13 & 1.282 \\
\hline M32. I usually use the same passwords in digital media. & 3.22 & 1.223 \\
\hline M33. I meet people I met in digital environments in real life. & 2.70 & 1.160 \\
\hline \multicolumn{3}{|l|}{ Dimension VI: Digital Skills } \\
\hline & 3.90 & .873 \\
\hline M34. I can edit my personal settings from my social media account. & 2.72 & 1.099 \\
\hline M35. I can easily use the digital tools (computer, smartphone etc.) for my need. & 4.12 & .945 \\
\hline M36. I can easily access the information I need via the Internet. & 4.37 & .790 \\
\hline M37. I can download and use the applications / programs I need from digital media. & 4.24 & .735 \\
\hline M38. When I have a problem with digital tools, I can fix this myself. & 4.08 & .800 \\
\hline \multicolumn{3}{|l|}{ Dimension VII: $\quad$ Digital Ethic } \\
\hline & 2.93 & .962 \\
\hline M39. I use someone else's ideas and thoughts without giving reference. & 3.73 & 1.004 \\
\hline M40. I know situations that infringe copyright. & 2.29 & .904 \\
\hline $\begin{array}{l}\text { M41. I use the content and information of others (photos, articles, graphics, etc.) without } \\
\text { permission. }\end{array}$ & 3.71 & .909 \\
\hline $\begin{array}{l}\text { M42. I do not upload copyrighted works such as movies, games and music in digital media } \\
\text { without paying the copyright. }\end{array}$ & 1.99 & 1.031 \\
\hline Dimension VIII: Digital Commerce & 3.91 & .989 \\
\hline M43. I prefer the website with the cheapest product. & 3.09 & 1.281 \\
\hline M44. I shop in digital media. & 2.96 & 1.186 \\
\hline M45. I consider product reviews when I choose a product or not. & 4.11 & .679 \\
\hline M46. I make sure that the websites I shop are corporate and reliable. & 4.29 & .672 \\
\hline M47. I note the information (name, phone, address, price) of the websites I shop for. & 4.58 & .705 \\
\hline M48. I prefer to do price research on the Internet before buying a product from digital media. & 3.96 & .818 \\
\hline M49. I know my rights about shopping that I do / will do through digital media. & 4.41 & .687 \\
\hline General Averages & 3.07 & .889 \\
\hline
\end{tabular}

When the table above is examined, items related to the 8 dimensions of the scale, mean and standard deviation values can be seen. In this context, since the overall average of all items for the relevant scale is 3.07 ; it is understood that the answers of the students generally focus on the "I am undecided" option.

Considering the general averages; it was determined that the highest average dimension was "digital commerce". In addition the scale item is with the highest average among 49 items: "I note the information (name, phone, address, price) of the websites I shop for". The scale item is with the lowest average among 49 items: "I click on any connection that comes to me in digital media". From this results; students were revealed to be aware of digital citizenship.

\subsection{Associating Students' Digital Citizenship Levels with Demographic Data}

Mann Whitney U and Kruskal Wallis $\mathrm{H}$ tests are used to determination of digital citizenship levels of university students. It is a non-parametric method used to compare the averages of two independent groups in a distribution that does not show normal distribution (Buyukozturk, 2018). Kruskal Wallis H test is a statistical test used to test the significance of the difference between the averages of three or more groups in groups that do not show normal distribution (Can, 2014). 


\subsubsection{Gender}

Table 2. Result of Gender Mann Whitney U Test Result

\begin{tabular}{ccccccc}
\hline Groups & $N$ & Rank Average & Row Total & $U$ & $p$ & Significant Difference \\
\hline Male & 179 & 138.96 & 2487 & 4483 & .000 & $\begin{array}{c}\text { There is a significant difference } \\
\text { between the groups. }\end{array}$
\end{tabular}

According to the table, $\mathrm{p}$ value is $.000<.05$; there is a significant difference between the digital citizenship levels of male students and the digital citizenship levels of female students. This difference is in favor of male students.

\subsubsection{Age}

Table 3. Result of Age Kruskal Wallis H Test Result

\begin{tabular}{ccccccc}
\hline Groups & $N$ & Rank Average & $S d$ & $X^{2}$ & $p$ & Significant Difference \\
\hline $18-21$ & 207 & 135.54 & & & & There is a significant difference \\
$21-24$ & 41 & 96.24 & 2 & 19.724 & .000 & $\begin{array}{c}\text { between the groups. } \\
25 \text { and more }\end{array}$ \\
\hline
\end{tabular}

According to the table, $\mathrm{p}$ value is $.000<.05$; there is a significant difference between the digital citizenship levels of $18-21 ; 21-24$ and 25 and more age. This difference is in favor of 18-21 age students.

\subsubsection{Department}

Table 4. Result of Department Kruskal Wallis H Test Result

\begin{tabular}{|c|c|c|c|c|c|c|}
\hline Group & $N$ & Rank Average & $S d$ & $X^{2}$ & $p$ & Significant Difference \\
\hline Information Tec. & 125 & 126.36 & & & & \\
\hline Manager & 55 & 135.64 & 4 & 5.533 & .237 & No significant \\
\hline Electronic & 27 & 126.33 & & & & between groups. \\
\hline Consructional Tec. & 44 & 123.51 & & & & \\
\hline Accounting & 2 & 15.50 & & & & \\
\hline
\end{tabular}

According to the table, $\mathrm{p}$ value is $.237>.05$; there is not a significant difference between the digital citizenship levels department of students.

3.1.4 Living Place

Table 5. Result of Living Place Kruskal Wallis H Test Result

\begin{tabular}{|c|c|c|c|c|c|c|}
\hline Group & $N$ & Rank Average & $S d$ & $X^{2}$ & $p$ & Significant Difference \\
\hline Province & 125 & 124.55 & & & & \\
\hline Distrinct & 55 & 133.71 & 4 & .854 & .836 & No significant \\
\hline Town & 27 & 124.33 & & & & between groups. \\
\hline Village & 44 & 121.51 & & & & \\
\hline
\end{tabular}

According to the table, $\mathrm{p}$ value is $.836>.05$; there is not a significant difference between the digital citizenship levels living place of students.

3.1.5 Mother's Educational Status

Table 6. Result of Mother's Educational Status Kruskal Wallis H Test Result

\begin{tabular}{|c|c|c|c|c|c|c|}
\hline Group & $N$ & Rank Average & $S d$ & $X^{2}$ & $p$ & Significant Difference \\
\hline Illiterate & 3 & 73.77 & & & & \\
\hline Primary school & 17 & 121.68 & 4 & 10.689 & .003 & There is a significant \\
\hline Secondary School & 96 & 135.32 & & & & between groups. \\
\hline High school & 137 & 142.94 & & & & \\
\hline University & 0 & 121.83 & & & & \\
\hline Master-PHD & 0 & & & & & \\
\hline
\end{tabular}


According to the table, $\mathrm{p}$ value is $.003<.05$; there is a significant difference between the digital citizenship levels mother's educational status of students. This difference is in favor of high school graduation.

3.1.6 Father's Educational Status

Table 7. Result of Father's Educational Status Kruskal Wallis H Test Result

\begin{tabular}{ccccccc}
\hline Group & $N$ & Rank Average & $S d$ & $X^{2}$ & $p$ & Significant Difference \\
\hline Illiterate & 13 & 113.34 & & & & \\
Primary school & 47 & 139.03 & 3 & 12.333 & .004 & There is a significant \\
Secondary School & 71 & 148.50 & & & & between groups. \\
High school & 113 & 165.38 & & & \\
University & 9 & & & & \\
Master-PHD & 0 & & & & & \\
\hline
\end{tabular}

According to the table, $\mathrm{p}$ value is $.004<.05$; there is a significant difference between the digital citizenship levels father's educational status of students. This difference is in favor of high school graduation.

3.1.7 Daily internet usage

Table 8. Result of Daily Internet Usage Kruskal Wallis H Test Result

\begin{tabular}{ccccccc}
\hline Group & $N$ & Rank Average & $S d$ & $X^{2}$ & $p$ & Significant Difference \\
\hline Hardly ever & 12 & 111.74 & & & & \\
Half an hour day & 10 & 122.93 & 4 & 10.390 & .002 & There is a significant \\
1 hour day & 23 & 138.53 & & & & between groups. \\
2 hours day & 46 & 121.89 & & & \\
3 hours and more & 162 & 159.93 & & & & \\
\hline
\end{tabular}

According to the table, $\mathrm{p}$ value is $.002<.05$; there is not a significant difference between the digital citizenship levels daily internet usage of students. This difference is in favor of 3 hours and more.

Table 9. The Relationship Between Daily internet usage with Digital Citizenship levels Results of Spearman Brown Correlation Coefficient

\begin{tabular}{llll}
\hline$N$ & $R$ & $p$ \\
\hline
\end{tabular}

Daily Internet Usage

$253 \quad .148 \quad .019$

\section{Digital Citizenship Levels}

According to the table, $\mathrm{p}$ value is $.002<.05$; there is not a significant difference between the digital citizenship levels daily internet usage of students. This difference is in favor of 3 hours and more. As seen in the table above, there is not significant relationship was found between the daily internet usage and digital citizenship levels $(\mathrm{r}=148$ and $\mathrm{p}>.05)$.

\section{Result and Discussion}

This study is aimed to determine the digital citizenship levels of university students. For this purpose, 253 students studied in various departments of the Hendek Vocational High School of Technical Sciences in Sakarya university. When the demographic characteristics of the students are examined; the age ranges ranged from under 18 to 50 and over, but the frequency was found to be $18-21$ age. It has been demonstrated that their department is often information technologies; where they live is often a province. In addition the education level of the parents of the students was found to be generally high school.

On the use of internet and mobile technologies; the most students do not have internet connection at home, the tool that is often connected to the often is the computer, the frequency of daily average time spent on the internet is 3 
hours and more and the purpose of using the internet is often to $\log$ in social media. When the tools they use to connect to the internet are examined, it is determined that young people use their smart phones. In addition, the presence of tools such as laptop, desktop computer, tablet, television point to in the study. In this context, TUIK 2019 data also found that $53.7 \%$ of individuals use smart phones to connect to the internet; desktop computers followed smart phones with $17.6 \%$. According to TUIK June 2019 when the data are analyzed, the active social media users in Turkey is 52 million individuals have been identified and the average daily spend time in 2 hours 46 mins social media. Tektaş (2014) found that the most frequently used device to connect to the internet is a mobile phone. In their study, Solmaz (2013) found that university students use social media extensively and spend approximately 1-3 hours a day in social networks. In addition, the aim of using social media has been revealed to be sharing photos and information, having fun and relaxing, having free time, having information and accessing information.

This research was carried out with the relational screening method, which is one of the quantitative research methods. "Digital Citizenship Scale for Youth" was developed by Kus, Gunes, Basarmak and Yakar (2017) the researcher as a data collection tool with permission. The scale has 49 items, the total variance of the scale was determined that the scale had 8 -factor structure and was found to be $49,70 \%$. The average for 49 items and 8 dimensions varied between 4.58 and 1.45. In this context, since the overall average of all items for the relevant scale is 3.07 ; it is understood that the answers of the students generally focus on the "I am undecided" option. Considering the general averages; it was determined that the highest average dimension was "digital commerce". In addition the scale item is with the highest average among 49 items: "I note the information (name, phone, address, price) of the websites I shop for". The scale item is with the lowest average among 49 items: "I click on any connection that comes to me in digital media". From this results; students were revealed to be aware of digital citizenship. When the literature is examined Erdem and Kocyigit (2019), they adapted the digital citizenship scale developed by Glassman and Cristol (2017) to Turkish. This scale is a Likert-type scale and consists of 26 items gathered under the factors of internet political activism, technical skills, local/global awareness, critical perspective and networking agency. As a result; the internal consistency test for the reliability of the scale puts forth that Cronbach Alpha coefficient is .87 for the total scale and the coefficient for the factors are $.86, .93, .83, .80$ and .73 respectively. The analyses prove a valid and reliable digital citizenship scale consisting of 18 items gathered under five factors.

In the context of Associating Students' Digital Citizenship Levels with Demographic Data; Mann Whitney U and Kruskal Wallis $\mathrm{H}$ tests are used to determination of digital citizenship levels of university students. There is a significant difference between the digital citizenship levels of male students and the digital citizenship levels of female students. This difference is in favor of male students. There is a significant difference between the digital citizenship levels of 18-21;21-24 and 25 and more age. This difference is in favor of 18-21 age students. There is not a significant difference between the digital citizenship levels department of students. There is not a significant difference between the digital citizenship levels living place of students. There is a significant difference between the digital citizenship levels father's educational status of students. This difference is in favor of high school graduation. There is a significant difference between the digital citizenship levels mother's educational status of students. This difference is in favor of high school graduation. There is a significant difference between the digital citizenship levels daily internet usage of students. This difference is in favor of 3 hours and more. The relationship between daily internet use and digital citizenship levels when Spearman Brown Correlation Coefficient Results are examined; there is not significant relationship was found between the daily internet usage and digital citizenship levels. In this context when the literature is examined; Yalcınkaya and Cibaroglu (2019), conducted an empirical research to examine the perception of digital citizenship. Gormez (2018), examined teacher candidates' opinions about the sub-dimensions of digital citizenship. It was revealed that pre-service teachers do not have sufficient information about other sub-dimensions other than digital commerce dimension. The relevant result is similar to research in this aspect.

\section{Suggestions}

In this study, the determination of digital citizenship levels was carried out in the sample group of university students. In future studies, sample groups of different levels can be studied.

Awareness trainings can be organized for all sample group of digital citizenship.

\section{References}

Akgün, E., Yılmaz, E. O. \& Seferoğlu, S. S. (2011). Vizyon 2023 strateji belgesi ve firsatları artırma ve teknolojiyi iyileştirme hareketi (FATIH) projesi: Karşılaştırmalı bir inceleme. XIII. Akademik Bilişim Konferansı (AB11) Bildirileri, 115-122. İnönü Üniversitesi, Malatya 
Apa, KUŞ, Z., Güneş, E. , Başarmak, U. \& Yakar, H . (2017). Development of a Digital Citizenship Scale for Youth: A Validity and Reliability Study. Journal of Computer and Education Research, 5(10), 03-12.

Bennett, W.L., Wells, C. \& Rank, A. (2009). Young citizens and civic learning: Two paradigms of citizenship in the digital age. Citizenship Studies, 13(2), 105-120.

Büyüköztürk, Ş., Kılıç Çakmak, E., Akgün, Ö.E., Karadeniz, Ş. \& ve Demirel, F. (2014). Bilimsel araştırma yöntemleri (17. Baskı). Ankara: Pegem Yayınları

Creswell, J. W. (2007). Qualitative inquiry \& research design choosing among five approaches. Sage Publications.

Dedebali, N. \& Dasdemir, I. (2019). Social Studies Teacher Candidates' Perception of Digital Citizenship. International Journal of Educational Methodology, 465-477.

Foster, J, Barkus, E \& Yavorsky, C. (2006). Understanding and Using Advanced Statistics, UK: Sage Publications.

Görmez, E. (2017). İlkokul sosyal bilgiler programının dijital vatandaşlık ve alt boyutları açısından yeterliliği. International Journal of Social Science, 2(60), 1-15.

ISTE (2014). Annual Report. https://id.iste.org/about/iste-story/annual-report/2014-annual-report accessed from 02.03.2020.

Jwaifell, M. (2018). The Proper Use of Technologies as a Digital Citizenship Indicator: Undergraduate English Language Students at Al-Hussein Bin Talal University. World Journal of Education, 8(3), 86-94.

Kanavel, K. (2014). Why is Digital Citizenship Important? Even for Youngest Kids. https://edtechreview.in/trends-insights/insights/1331-why-is-digital-citizenship-important-even-for-youngest-kid $\mathrm{s}$

Karaduman, H. \& Ozturk, C. (2014). Sosyal Bilgiler Dersinde Dijital Vatandaşlığa Dayalı Etkinliklerin Öğrencilerin Dijital Vatandaşlık Tutumlarına Etkisi ve Dijital Vatandaşlık Anlayışlarına Yansımaları. Journal of Social Studies Education Research, 5(1), 38-78.

Ribble, M. \& Bailey, G. (2007). Digital Citizenship in Schools. Washington, DC: ISTE. ISBN:978-1-56484-232-9.

Solmaz, B., Tekin, G. Herzem, Z. \& Demir, M. (2013). Internet ve sosyal medya kullanımı üzerine bir uygulama. Selçuk İletişim, 7(4), 24-32

Tawalbe, H. (2017). Digital Citizenship in the National Civic Education Textbook: An Analytical Study. The Jordanian Journal of Educational Sciences, 13(3), 291-208.

Tektaş, N. (2014). Üniversite öğrencilerinin sosyal ağları kullanımlarına yönelik bir araştırma, Tarih Okulu Dergisi (TOD), XVII, pp. 851-870,

TUIK, (2019). Türkiye İstatistik Kurumu (TUiK), Hanehalkı Bilişim Teknolojileri Kullanım Araştırması. https://dijilopedi.com/2019-tuik-hanehalki-bilisim-teknolojileri-kullanim-arastirmasi/ accessed from 02.03.2020.

Vural, S., S. \& Kurt, A., A. (2018). Üniversite Öğrencilerinin Bakış Açısıyla Dijital Vatandaşlık Göstergelerinin İncelenmesi. Eğitim Teknolojisi Kuram ve Uygulama, 8(1), 60-80. https://doi.org/10.17943/etku.317713

Yalcınkaya, B. \& Cibaroglu, M., O. (2019). Nesnelerin İnternetine Genel Yaklaşımlar: Bilgi Yönetiminde Nesnelerin Interneti, 6(1), 1-15. 